\title{
A HUMAN CROWD EFFECT MODELLED BY THE DISCRETE-TIME FOURIER SERIES
}

\author{
UDC 519.6:241.1
}

\author{
Miomir Jovanović ${ }^{1}$, Goran Radoičić ${ }^{2}$ \\ ${ }^{1}$ University of Niš, Faculty of Mechanical Engineering, Niš, Serbia \\ ${ }^{2}$ Public company "Mediana" Niš, Serbia
}

\begin{abstract}
Accidental actions caused by vibrations of supporting structures in mechanical systems represent the dynamic tasks of specific scientific and professional research in the field of human and equipment safety. This paper determines the mathematical model of physical excitation force created by human power, based on the discrete-time Fourier transformation. For experimental verification of the model, we made a special platform for measuring bouncing force of people who create natural impulse oscillation. The paper shows the results of individual and group experimental testing of living force as the cause of accidents and dangerous effects on the structure. In the end, the excitation of the human operation of a malicious nature (heavy transport machine - crane) has been used to show the application of Fourier model to simulate one incident. For this purpose, the transient FEM analysis and the eigenvalues predetermined modal analysis are used. The paper is illustrated with photographs of experimental tests of dangerous human impulse in several working machines (objects).
\end{abstract}

Key words: accident, living human force, modelling, transient and modal analysis, vibration.

\section{INTRODUCTION}

Living human force has been known to cause critical states of facilities for a long time. The pulse effect in the form of rocking, swinging or synchronous bouncing (by dynamic excitation force) may increase mechanical action on the structure. That action can be enough to cause an incident (breakdown) in the form of overturning in the case of systems with limited stability. Especially, living human effect can be risky when it takes place in a resonant mode with more frequently synchronized people.

National experimental investigations carried out on elastic support structures of cranes in the last 30 years [1-4] show the dynamic sensitivity in various forms of inattention

Received April 8, 2017 / Accepted July 13, 2017

Corresponding author: Goran Radoičić

Public company "Mediana", Mramorska 10, 18000 Niš, Serbia

E-mail: goran.radoicic@jkpmediana.rs 
when handling. Inattention is often manifested through risk, incidents and damages. Risk caused by small mechanical work, i.e. by energy that people can create only from their physical strength is particularly interesting. In 1996, Great Britain adopted the standard BS 6399-1 BS [5] which relates to live actions. Littler [6] introduced in 2003 a mathematical model of live action induced by jumps and impacts. In 2006, Sahnaci and Kasperski presented a model of random loads induced by walking [7]. Behnia et al. [8] provided a review of several load models: Half-Sine Pulse (proposed by Bachmann and Ammann 1987), Dynamic loading using Fourier series (based on summing up a group of sine waves of various frequencies, magnitudes and phases, convenient for human loading) and expansion to crowds, according to the relation:

$$
F_{v}(t) N=C(N) \cdot Q \cdot\left[1+\sum_{n=1}^{k} \alpha_{n, v} \cdot \sin \left(2 \pi \cdot f \cdot n \cdot t+\Phi_{n v}\right)\right]
$$

The model of crowd loads is defined by the magnitude of applied load at time for a crowd of $\mathrm{N}$ people $F_{\mathrm{v}}(t)$ as a product of the coordinating factor $\mathrm{C}(\mathrm{N})$ of a size $\mathrm{N}$ group (the event is based on the crowd load of at least 20 persons), $Q$ is the weight of associated crowd, $k$ is the DLF number, $\alpha_{n}$ is the $n$-th rhythmic (DLF) coefficient which is represented by different people in different activities, $f$ is the activity frequency and $\Phi_{n v}$ is the phase lag of the $n$-th harmonic of the load. The ISO 10137 standard (2007) defines the rhythmic coefficient as $\alpha_{n}=0.8$ maximally and $\alpha_{n}=0.5$ minimally in the first harmonic. The values of this coefficient are $\alpha_{n}=0.67$ according to BS 6399-1 (1996) and $\alpha_{n}=0.75$ according to Bachmann and Ammann (1987). There are also newer load models based on random actions (Vakulenko and Cherkai [9], 2010) and the duration of the contact between feet and the base (De Silva and Thambiratnam [10], 2009).

This paper, in the further course, first exposes the original experimental research on a simple mechanical model (stand) and then on a real supporting structure of the bridge crane with trail. The results of numerical simulation of the bridge crane and comparison with the results of the experiment are given at the end of the paper.

\section{A SIMPLE EXPERIMENT WITH LIVING HuMAN FORCE}

By starting research effect of living human force on facilities one question was asked: How does the disturbance force created by one person's energy look like? For this purpose a test platform to measure the vertical bouncing force by people (several persons) was made, Fig. 1. The test platform is equipped with a force transducer HBM U2A and acceleration sensor Philips. The measurement was performed with full six-channel measuring bridges with feedback between the amplifier and sensors. Measured results (Measurement no.15, TEST1_014, April 22, 2015, start time 11:34 AM) of the bouncing force by an adult male person (Measurement no.3) without separation from the upper surface of the platform and medium intensity of effect between limits $\mathrm{Rp}=1 \div 3$ are shown on the diagrams in Fig. 2. On the force diagram (Fig. 2) one can see that the dynamic change of force has a periodic harmonic character and intensity conditioned by the intention to obtain uniform scope of excitation between $9^{\text {th }}$ and $23^{\text {rd }}$ second of the experiment. This resulted in the maximum ratio of dynamic and static force (dynamic coefficient) of 2.4 and maximum acceleration of the tread surface of $6.85 \mathrm{~m} / \mathrm{s}^{2}$. This and other experimental results [11] with more persons on the platform indicate the possibility for theoretic modeling of 
live human force using Fourier series as proposed by Bachmann and Ammann 1987. This model is based on the summation of individual sine semi-waves or full waves caused by various excitation frequencies. One can see that the living human force has not a constant amplitude but that it is conditioned by the individual development (case). Consequently it, is necessary to introduce an additional function amplitude of the resulting force which is caused by the process of growth force - excitation of the facility from hibernation.

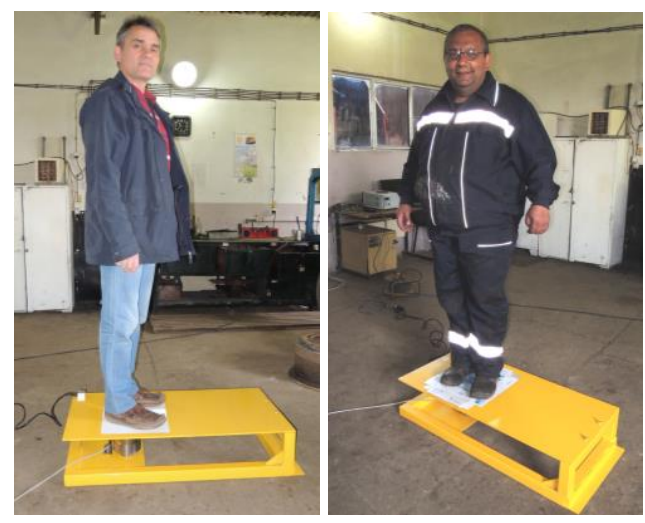

Fig. 1 Examination of living force caused by action of different people on the test stand
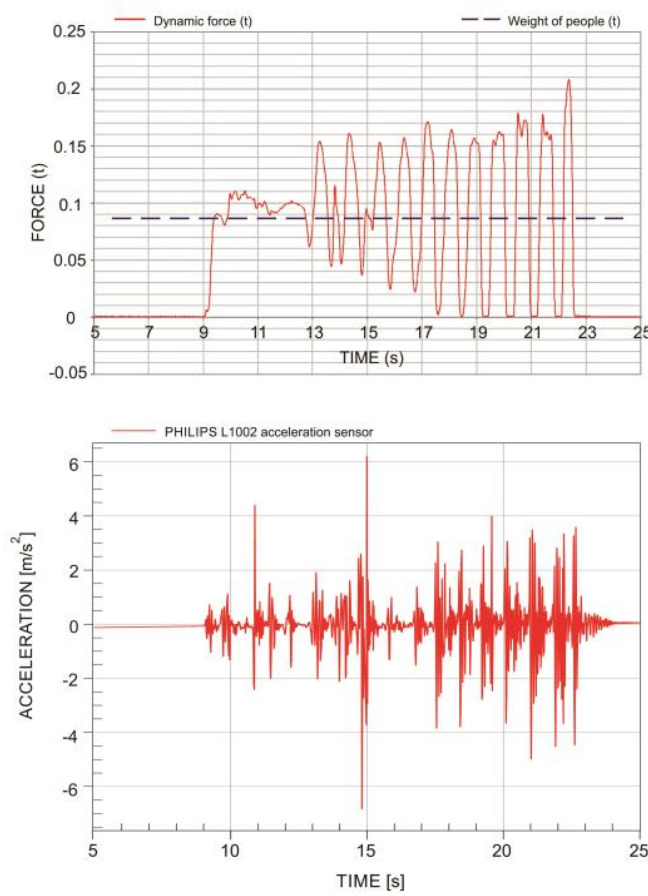

Fig. 2 Experiment No.15: Living human force $\mathrm{F}(\mathrm{t})$ [tons] and test stand acceleration $\mathrm{a}_{\mathrm{y}}\left[\mathrm{m} / \mathrm{s}^{2}\right]$ in the vertical direction caused by vibration 


\section{Setting the TheORETiCAl Model of the LiVing Human ForCe}

In order to implement previous observations about the live human force character on a real object - elastic supporting structure of crane, the following assumptions have been made:

- Modelling the incident as a dynamic event caused by a malicious action on heavy lifting machines.

- Modelling a malicious dynamic excitation on the main crane carrier according to the performed experiment, Figs. 2 and 3.

- The excitation is created by the effect of two persons $(i=2)$ as their own live force at bouncing on the main carrier of the crane.

- The excitation is characterized by the synchronicity of individual living actions $F_{i}(t)$.

- Oscillation mass $M_{i}$ of people who caused the excitation were known and frequency $\Omega$ was measured.

- The damping force is proportional to the nearest modal frequency $\left(\omega_{17}\right)$ - the excitation frequency $(\Omega)$.

- The excitation is characterized by a monotonous growth and reducing amplitudes of stress according to each experiment performed, Fig. 3.

- The duration of excitation in the experiment and number of oscillations to the rest of process is known.

- The amplitude of vertical translation due to the excitation of forced living force is experimentally determined.

- Boundary conditions of the experiment are known: Initial excitation time $t_{0}$, end time of excitation $t_{\mathrm{K}}=t_{7}$, and characteristic excitation times: $t_{1}, t_{2}, t_{3}, t_{4}, t_{5}, t_{6}, t_{7}$.

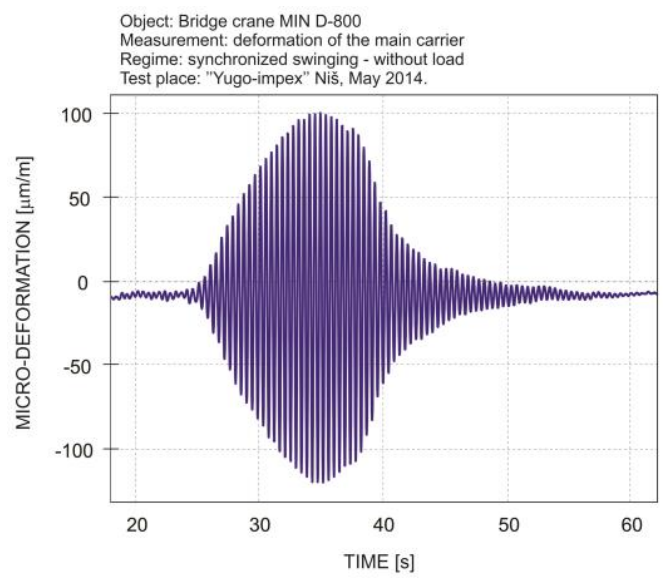

Fig. 3 Diagram of longitudinal strain deformation of the main box girder of bridge crane during malicious crane swinging with two persons (Measuring no.11, May 2014)

According to Eq.(2) on the basis of previous features of the crane bouncing process and dynamic load described by Fourier series [8], a multiplicative oscillatory linearized function of excitation is set. This multiplicative function $F_{M}(t)$ is a product of people weight $G_{0}$, linearized countur amplitude function $F_{L}(t)$ and harmonic function $F_{H}(t)$. Value of the maximum amplitude of excitation human weight force $G_{0}$ is determined on 
the basis of experimental testing and it has individual character. $G_{0}$ is the force of a group of people $N$ with individual mases $M_{N}$ which cause the live human force. In this numerical model with the load of two people, value of the force is $G_{0}=2 \times 1000 \mathrm{~N}$. Synchronization of load is complete i.e. $\alpha=1$.

$$
F_{M}(t)=G_{0} \cdot\left[1+F_{L}(t) \cdot F_{H}(t)\right]
$$

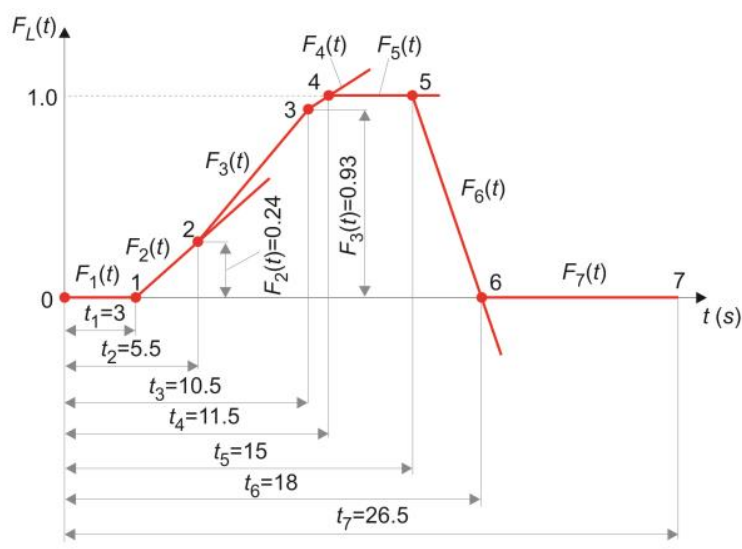

Fig. 4 The general model of contour amplitude function

In general, the contour amplitude function $F_{L}(t)$, Fig. 4 , is determined by linear approximation of the stress/strain growth experimentally obtained and shown in Fig. 3. This function is formed from seven chronological successive functions $F_{n}(t)(n=1 \div 7)$ introduced by Eq.(3). The harmonic excitation function $F_{H}(t)$ at the forced frequency $\Omega$ is represented in further text as the sine function, Eq.(4). The multiplicative oscillatory linearized function of excitation, Eq.(2), then takes a characteristic theoretical form which is shown in Fig. 5.

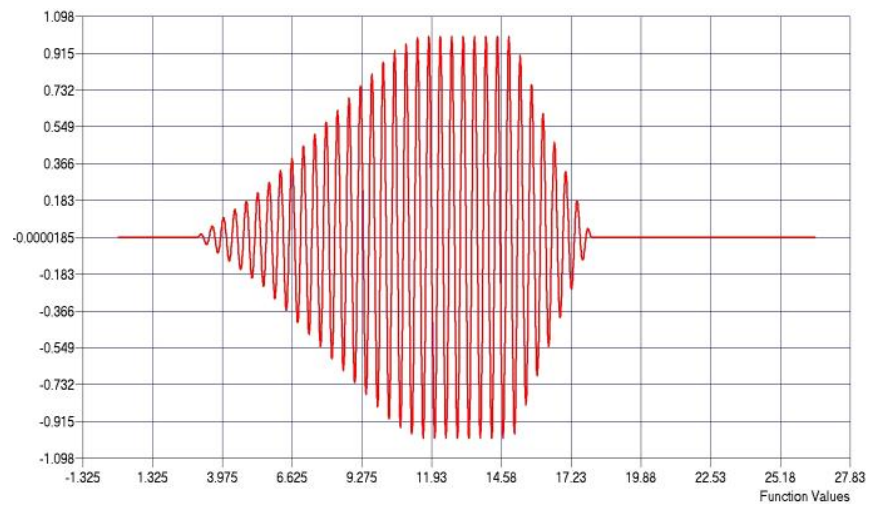

Fig. 5 The multiplicative oscillatory linearized function of excitation.

The parameters of applied function $\mathrm{F}_{\mathrm{L}}(\mathrm{t}): \mathrm{t}_{0}=0 \mathrm{~s}, \mathrm{t}_{1}=3 \mathrm{~s}, \mathrm{t}_{2}=5.5 \mathrm{~s}, \mathrm{t}_{3}=10.5 \mathrm{~s}, \mathrm{t}_{4}=11.5$ $\mathrm{s}, \mathrm{t}_{5}=15 \mathrm{~s}, \mathrm{t}_{6}=18 \mathrm{~s}, \mathrm{t}_{7}=26.5 \mathrm{~s}, \mathrm{~F}_{2}=0.24, \mathrm{~F}_{3}=0.93, \mathrm{~F}_{6}=0, \Omega=2.306 \mathrm{~Hz}$ 


$$
F_{L}(t)=\left\{\begin{array}{l}
F_{1}(t)=0, \quad t=0 \div t_{1} \\
F_{2}(t)-0=\frac{F_{2}-F_{1}}{t_{2}-t_{1}}\left(t-t_{1}\right), t=t_{1} \div t_{2} \\
F_{3}(t)-F_{2(t=t 2)}=\frac{F_{3}-F_{2}}{t_{3}-t_{2}}\left(t-t_{2}\right), t=t_{2} \div t_{3} \\
F_{4}(t)-F_{3(t=t 3)}=\frac{1-F_{3}}{t_{4}-t_{3}}\left(t-t_{3}\right), t=t_{3} \div t_{4} \\
F_{5}(t)=1, \quad t=t_{4} \div t_{5} \\
F_{6}(t)-1=\frac{F_{6}-1}{t_{6}-t_{5}}\left(t-t_{5}\right), t=t_{5} \div t_{6} \\
F_{7}(t)=0, \quad t=t_{6} \div t_{7} \\
F_{H}(t)=\sin (\Omega \cdot t)
\end{array}\right.
$$

\section{NUMERICAL SIMULATION}

Transient analysis has nonlinear character. So, according to the author's choice, an acceptable solution may be required using the Newmark method of time integration. In this way, the system of equations for the geometric nonlinear structural dynamics can be written at time $t+\Delta t$ as:

$$
\mathbf{M}^{t+\Delta t} \ddot{\mathbf{q}}^{(k)}{ }_{+}{ }^{t+\Delta t} \mathbf{C}^{t+\Delta t} \dot{\mathbf{q}}^{(k)}{ }_{+}{ }^{t+\Delta t} \mathbf{K}_{\mathbf{T}}{ }^{t+\Delta t}{ }_{\Delta \mathbf{q}}{ }^{(k)}={ }^{t+\Delta t} \mathbf{f}_{\mathbf{e x t}}{ }^{-{ }^{t+\Delta t} \mathbf{f}_{\text {int }}}{ }^{(k-1)}
$$

Where: $\mathbf{M}$ is the matrix of inercial coefficients of the model, $\mathbf{C}$ is damping matrix, $\mathbf{K}_{\mathbf{T}}$ is the tangential matrix of stiffness, $\Delta t$ is the increment of time, $k$ is the ordinal number of numerical iterations.

\subsection{Bridge crane modelling}

The discrete FE model of bridge crane is based on a real crane of manufacture type MIN-D800 (the owner: company JUGOIMPEX-Niš) with the range of $L=30 \mathrm{~m}$, carrying capacity of $Q=5 \mathrm{t}$ and mean structural elasticity on the bending. The crane is characterized by the total mass of $17.2 \mathrm{t}$ and carriers of medium stiffness $(L / f=424>250$, where $f$ is the deflection of the mid-range). For the needs of this research the authors developed a model including the crane trail and support masts.

The numerical model has 15786 finite elements and 87982 algebraic equations (degrees of freedom). The model was solved using MSC NASTRAN software, Fig. 6. Very high fidelity of the model in relation to the physical object (crane) is enabled by introducing the crane trails and support masts. 


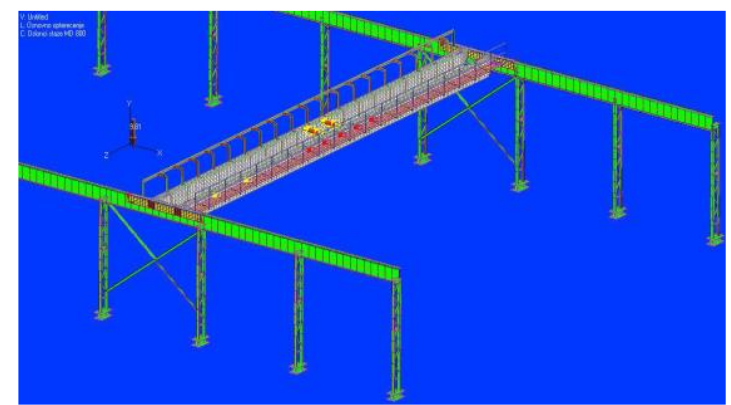

Fig. 6 FEM model of the bridge crane MIN-D800 with trail and supports in numerical simulation

\subsection{The solution of simulation for living force excitation}

After numerical integration of differential equations (in the direct transient analysis) which describe the numerical model of the bridge crane, a response of the main crane carrier on the living force excitation is obtained on the basis of the adopted step integration of $20 \mathrm{~ms}$ in a separate time interval from Fig. 5. The solution of numerical integration in the form of vertical translation of the node in the middle of the carrier range in time function is shown in Fig. 7. The excitation was modeled as an action of two people on the carrier by synchronous bouncing at its lowest eigenfrequency. The first group vibration from the diagram in Fig. 7 (up to 10 seconds) is caused by calming the carrier due to a static force introduced in the model - the own weight of people (exciter).

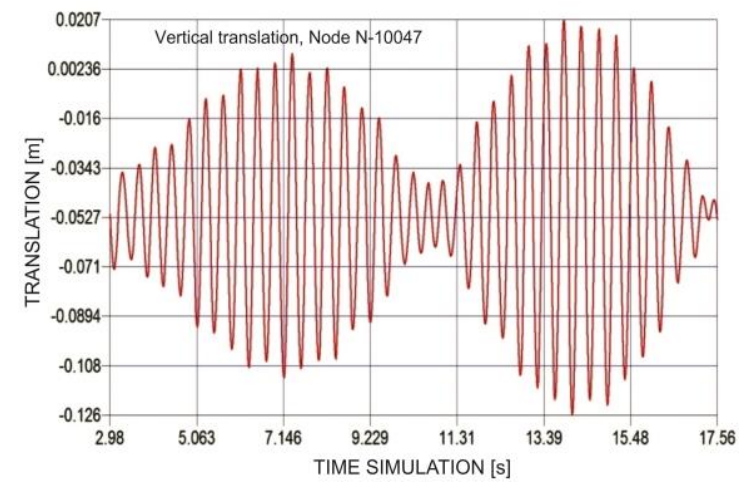

Fig. 7 Bridge crane D800: Numerical vibration of the main carrier in the node on the middle of the range

\section{EXPERIMENTAL VERIFICATION}

For the observed case of incident, an experiment on a real object was carried out. The vertical vibration of the middle of the carrier as an experimental result is shown in Fig. 8. The vibration shape numerically computed, Fig. 7, is very similar to the experimental translations of the mechanical system with damping, Fig. 8. That small difference lies in 
a longer time interval, that is, a larger number of vibrations. The numerical computed amplitudes of vibration in total amount $2 \mathrm{~A}_{\mathrm{N}}=0.14 \mathrm{~m}$ (Fig. 7) while the experimentally measured amplitudes amount $2 \mathrm{~A}_{\mathrm{E}}=0.118 \mathrm{~m}$, (Fig. 8). The difference is caused by the influence of the damping due to which the experimental translation has less amplitude.

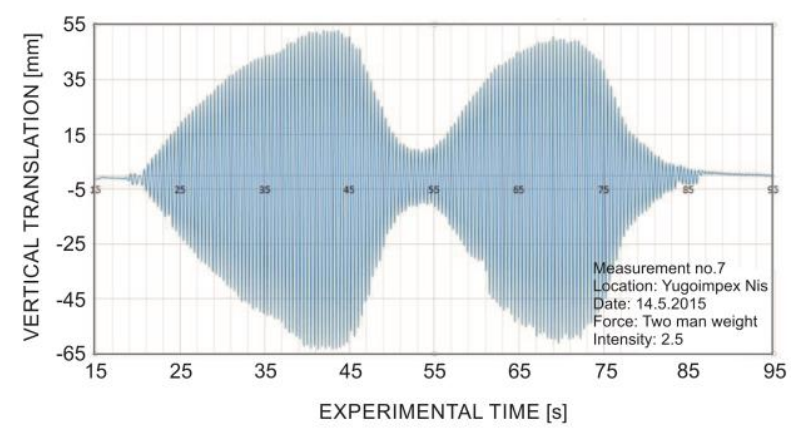

Fig. 8 Experiment (MIN D800): Simulation of the main carrier vibration in the node on the middle of the range

Verification of the simulation model of the crane MIN-D800 is performed on the basis of the comparison of two static sizes, stress and deflection due to the lifting a weight of 4 tons as well as a dynamic size - vibration frequency, [12]. Thus, a high approximation of the results is obtained. The longitudinal static stress numerically computed at the load of 4 tons is $1.945 \mathrm{kN} / \mathrm{cm}^{2}$ while the experimentally measured mean stress is $2 \mathrm{kN} / \mathrm{cm}^{2}$. The total deflection numerically obtained is $0.0704 \mathrm{~m}$ (model D800/ver.7) while the deflection of load is $0.0201 \mathrm{~m}$. The deflection of $0.019 \mathrm{~m}$ is measured experimentally at the load of 4 tons (model D800 /ver.4).

In the modal (numerical) analysis that was performed in the second step the eigenfrequencies and eigenvectors of vibration are obtained, [12]. The eigenfrequency of free bridge crane vibration without damping is numerically obtained and amounts $\omega_{17}=2.306 \mathrm{~Hz}$ (without load). This eigenfrequency numerically computed is then experimentally verified using the frequency determined from the diagram in Fig. 8 on the basis of the period of vibration $\mathrm{T}=0.4602 \mathrm{~s}$ (eigenfrequency $\omega_{17}=2.173 \mathrm{~Hz}$, Table 1 ).

The crane model is experimentally verified using the three checks (stress, deflection, eigenfrequency) which further enabled its application in the modelling dynamic simulation. The model has agreed with the experiment only after introducing the crane trail supported by the vertical truss carriers in the simulation. Fig. 9 shows a characteristic mode shape of the simulation model at a frequency which can easily create a couple of people.

Table 1 Comparison of deflections and eigenfrequencies

\begin{tabular}{lcc}
\hline Type of analysis & $\begin{array}{c}\text { Load deflection } \\
\Delta y_{Q}[\mathrm{~m}]\end{array}$ & $\begin{array}{c}\text { Eigenfrequency } \\
\omega[\mathrm{Hz}]\end{array}$ \\
\hline Nonlinear static & 0.0201 & $\times$ \\
Normal modal & $\times$ & 2.306 \\
Experimental & 0.019 & 2.173 \\
Relative deviation & $5.79 \%$ & $6.12 \%$ \\
\hline
\end{tabular}




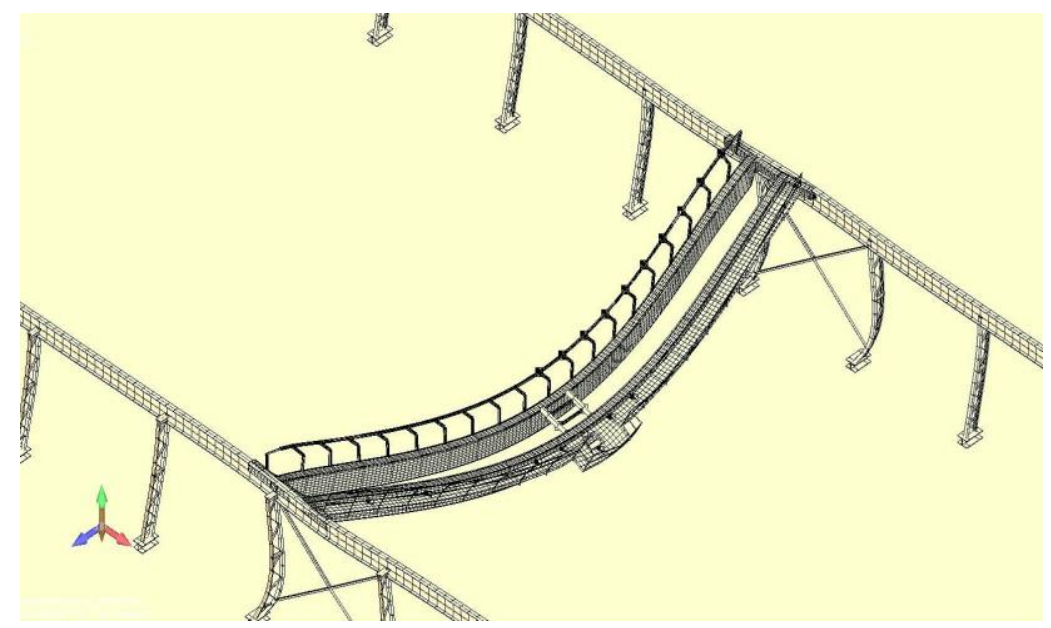

Fig. 9 Modal analysis: Mode-17 $\left(\omega_{17}=2.306 \mathrm{~Hz}\right)$ as a vibration form of crane MIN-D800

\section{CONCLUSION}

These studies developed and verified the models that define practical simulation procedure of incidents on the cranes. The proposed simulation models are rational regarding the number of degrees of freedom and the practical realization using a standard computer on today's level. It allows all shapes and durations of simulation as well as various modalities of external incidental influences. The proposed models can be applied in the practice for individual technical solutions.

For bridge cranes with longer ranges and small carrying capacity $(30 \mathrm{~m} / 5 \mathrm{t})$, as well as small relative static stiffness of the main carrier $(l / y<400)$, it has been observed that there is a sensitivity of the structure on the occurrence of higher amplitudes of vibration after the experimental investigations and simulations. The risk occurs in a relative small energy of excitation which only a few people have. The incident can cause the fall of the winch off the track.

The developed numerical models give the results of dynamical simulations for a group of separated dynamical influences. The same models can be used for further investigations of other new types of incidental effects using primarily numeric as a basis for the effective realization.

Malicious effects of people can cause significant vibrations, increase of stress and deflection of structure and even, in the case of bridge crane, the winch fall off the track. It is necessary to increase lowest stiffness of the crane carriers and introduce monitoring of the exploitation, considering that a relative small human force can create a very risky state of the stability of elastic objects. In order to protect the human potential of unforeseeable influences it is necessary to apply more frequent remote control of cranes and remove man further from the crane. 
Acknowledgement: The paper is a part of the research performed within the project TR-35049 at the Faculty of Mechanical Engineering in Niš. The authors would like to thank the Ministry of Education, Science and Technological Development of the Republic of Serbia for the support in the research.

\section{REFERENCES}

1. Jovanović M., (1990), Supporting structure level luffing system and driving mechanisms resistance of portal-jib cranes optimization, University of Niš, Faculty of Mechanical Engineering, Doctor's work.

2. Jovanović M., Mijajlović D., Petković Lj. and Jovanović J., (2000), Deseleration time of vibrationparameter of geometric supporting structures synthesis, Int. Conf. "Noise and Vibration", University of Niš, Faculty of Occupational Safety.

3. Jovanović M. and Radoičić G., (2014), Dynamical response of structures to malicious and random actions, The $5^{\text {th }}$ Int. Conf. “Transport and Logistics - TIL 2014", Niš, $5^{\text {th }}-6^{\text {th }}$ June 2014, pp. 51-54.

4. Jovanović M., Radoičić G. and Milić P., (2009), Dynamic sensitivity research of portal-rotating cranes, XIX Int. Conf. on "Material Handling, Constructions and Logistics - MHCL'09", Belgrade, $15^{\text {th }}-16^{\text {th }}$ October 2009, pp. 61-66.

5. British Standards Institution, BS 6399-1:1996, Loading for buildings, British Standard Inst., 1996.

6. Littler J.D., (2003), Frequencies of synchronized human loading from jumping and stamping, The Structural Engineer, Vol. 22, pp. 27-35, 2003.

7. Sahnaci S. and Kasperski M., (2005), Random loads induced by walking, Structural Dynamics, EURODIN-2005, Vol. 1, pp. 441-446, Millpress, Rotterdam 2005.

8. Behnia A., Beng Hong A.K., Shabazi M.M., Ranjbar N., Behnia N. and Vafaei M.R., (2013), Finite element analysis of high modal dynamic responses of a composite floor subjected to human motion under passive live load, LA Journal of Solids and Structures, Vol. 10, No. 3, pp. 601-630, 2013.

9. Vakulenko S.A. and Cherkai M.V., (2010), Destruction of dissipative structures under random actions, Theoretical and Mathematical Physics, Vol. 165, Issue 1, pp. 1387-1399, 2010.

10. De Silva S.S. and Thambiratnam D.P., (2009), Dynamic characteristics of steel-deck composite floors under human-induced loads, Computers \& Structures, Vol. 87, Issues 17-18, pp. 1067-1076, 2009.

11. Jovanović M. and Radoičić G., (2015), Experimental research of dynamical live-load on the platform in company Mediana-Niš, Faculty of Mechnical Engineering Niš, Internal report of the Project TR35049.

12. Jovanović M., Radoičić G., Jovanović V. and Tomić V., (2015), Synchronic excitation - a type of malicious dynamic action, XXI Int. Conf. on "Material Handling, Constructions and Logistics MHCL'15”, Vienna, $23^{\text {th }}-35^{\text {th }}$ September 2015, pp. 207-210.

\section{MODELIRANJE DEJSTAVA ŽIVE LJUDSKE POBUDE NA MEHANIČKI SISTEM PRIMENOM DISKRETNOG FURIJEOVOG REDA}

Incidentna dejstva koja izazivaju vibracije nosećih struktura mehaničkih sistema, predstavljaju klasu dinamičkih zadataka specifičnih naučnih i profesionalnih izučavanja bezbednosti ljudi $i$ opreme. Ovim radom se utvrđuje matematički model fizičke sile pobude koju može stvoriti čovek sopstvenom snagom, na bazi diskretne Furijeove transformacije. Za potrebe eksperimentalne verifikacije modela konstruisana je specijalna test platforma za merenje sile poskakivanja ljudi koji stvaraju prirodno impulsno oscilovanje. Rad pokazuje rezultate merenja žive ljudske sile u slučajevima individualne $i$ grupne pobude što može biti uzrok incidenata i opasnih dejstava na strukturu. U radu je pokazana primena pobude malicioznim ljudskim dejstvom predstavljene Furijeovim modelom za simulaciju jednog incidenta, na primeru teške transportne mašine dizalice. U ovom istraživanju primenjene su tranzijentna FEM analiza i normalna modalna analiza. Rad je ilustrovan fotografijama i dijagramima sa eksperimentalnih proba opasnog ljudskog impulsnog dejstva na nekoliko različitih radnih mašina (objekata).

Ključne reči: incident, modeliranje, tranzijentna i modalna analiza, vibracije, živa ljudska sila 